\title{
INTERPRETATION APPROACH IN THE DYNAMICS OF SHARIA BANKING
}

\section{PENDEKATAN TAFSIR DALAM DINAMIKA PERBANKAN SYARIAH}

\author{
P-ISSN: 2085-5818 | E-ISSN: 2686-2107 \\ Url Jurnal: https://uia.e-journal.id/Al-Risalah/article/1471 \\ DOI : 10.34005/alrisalah.v12i2.1471
}

Naskah Dikirim: 13-07-2021 Naskah Direview: 14-07-2021 Naskah Diterbitkan: 15-07-2021

\section{ZAMAKHSYARI ABDUL MAJID}

\author{
UIN Syarif Hidayatullah Jakarta
}

\section{zamakhsyari am@yahoo.co.id}

\begin{abstract}
Indonesia is a country with the largest Muslim population in the world with a Muslim population of around 204 million. This large Muslim population represents a great potential for the development of Islamic banking. This Islamic banking began to get the government's attention with the issuance of a law that supports Islamic banking. With various policies and decisions from a period of approximately 36 years (1974-2008), starting with the holding of a national seminar on relations between Indonesia and the Middle East which contained the idea of realizing the Islamic Banking Law. This article is a qualitative study. The existence of Islamic-based Rural Banks encourages the establishment of interest-free commercial banks. With various developments that continue to be carried out by the Indonesian Banking, in 2008 the enactment of Law no. 21 of 2008 concerning Islamic Banking which is expected to provide significant prospects for Islamic Banking. Basically the concept in Islam cannot be separated from the 5 pillars of primary needs (al-dlaruriyyatul al-khams), namely: hifdhun nafs (guaranteed protection of the soul), hifdhul 'aql (guaranteed protection of reason), hifdhul mâl (guarantee of property protection), hifdhun nasl (guaranteed protection of offspring), and hifdhud dn (guaranteed protection of religion).
\end{abstract}

Keywords: Tafsir Approach, Sharia Banking, Global Dynamic

\begin{abstract}
Abstrak: Indonesia merupakan negara dengan populasi Muslim terbesar di dunia dengan jumlah penduduk muslimnya sekitar 204 juta jiwa. Populasi Muslim yang besar ini merupakan potensi besar bagi perkembangan perbankan syariah. Perbankan syariah ini mulai mendapat perhatian pemerintah dengan dikeluarkannya undang-undang yang mendukung perbankan syariah. Artikel ini merupakan studi kualitatif. Dengan berbagai kebijakan dan keputusan dari kurun waktu kurang lebih selama 36 tahun (1974-2008), dimulai dari diselenggarakannya seminar nasional hubungan antara Indonesia-Timur Tengah yang berisikan tentang ide merealisasikan UU Perbankan Islam. Keberadaan Bank-bank Perkreditan Rakyat yang berbasis Islam tersebut mendorong untuk didirikannya bank umum yang bebas bunga. Dengan berbagai perkembangan yang terus di lakukan oleh Perbankan Indonesia, pada tahun 2008 disahkannya UU No. 21 Tahun 2008 tentang Perbankan Islam yang diharapkan memberikan prospek yang signifikan bagi Perbankan Islam. Pada dasarnya konsep dalam Islam itu tidak lepas dari 5 pilar kebutuhan primer (aldlaruriyyatul al-khams), yaitu: hifdhun nafs (jaminan perlindungan jiwa), hifdhul 'aql
\end{abstract}


(jaminan perlindungan akal), hifdhul mâl (jaminan perlindungan harta), hifdhun nasl (jaminan perlindungan keturunan), dan hifdhud dîn (jaminan perlindungan agama).

Kata kunci: Pendekatan Tafsir, Perbankan Syariah, Dinamika global

\section{A. PENDAHULUAN}

Perbankan merupakan lembaga keuangan terpenting bagi pembangunan suatu negara. Hal ini disebabkan karena fungsi dari perbankan adalah sebagai lembaga intermediasi keuangan (financial intermediary institution) sebagaimana ditegaskan dalam Pasal 1 angka 2 Undang-Undang Nomor 10 Tahun 1998 tentang Perubahan Atas UndangUndang Nomor 7 Tahun 1992 yakni bahwa Bank adalah badan usaha yang menghimpun dana dari masyarakat dalam bentuk simpanan dan menyalurkannya kepada masyarakat dalam bentuk kredit dan atau bentuk-bentuk lainnya dalam rangka meningkatkan taraf hidup rakyat banyak.

Pentingnya eksistensi dan kedudukan lembaga perbankan dimaksud membuatnya sarat mendapatkan pengaturan dari tataran konstitusi hingga pengaturan di tataran teknis. Bank Indonesia sebagai pemegang otoritas keuangan dan perbankan telah mengeluarkan berbagai regulasi terkait dengan praktik perbankan, serta melakukan supervisi dan pengawasan agar kalangan perbankan benar-benar melaksanakan berbagai peraturan di bidang perbankan. Ketaatan institusi perbankan terhadap berbagai peraturan akan berdampak bagi peningkatan kepercayaan masyarakat terhadap bank, dimana kepercayaan merupakan ruh dari industri perbankan itu sendiri.

Di sisi lain umat Islam sebagian besar masih belum dapat menerima bank, bukan karena tidak percaya akan arti pentingnya bank bagi proses pembangunan akan tetapi karena bank-bank dimaksud mendasarkan pada sistem bunga (interest based). Bunga oleh sebagian besar umat Islam dianggap merupakan riba yang secara jelas dan tegas dilarang oleh ajaran Islam sebagaimana tertuang dalam al- Quran dan Hadis Nabi Muhammad SAW. ${ }^{1}$

Bagi umat Islam di Indonesia adanya pendapat bahwa bunga bank sama dengan riba dipertegas dengan keluarnya Fatwa Majelis Ulama Indonesia tentang keharaman bunga bank yang merupakan hasil lokakarya para ulama tentang bunga bank dan perbankan di Cisarua, Bogor tanggal 19-22 Agustus 1990. Dalam lokakarya tersebut sebenarnya muncul dua pandangan yang berbeda terhadap bunga bank, yakni: (1) pendapat yang menyatakan bahwa bunga bank itu riba dan oleh karena itu hukumnya haram; (2) pendapat bahwa bunga bank bukan riba dan oleh karena itu diperbolehkan, dengan alasan "rukshah". ${ }^{2}$

\footnotetext{
1 Abdul Ghofur Anshori, "Sejarah Perkembangan Hukum Perbankan Syariah di Indonesia dan Implikasinya bagi Praktik Perbankan Nasional", Jurnal Ekonomi Islam, Vol. II, No. 2, Desember 2008 2 Zainul Arifin (1999), "Memahami Bank Syariah: Lingkup, Peluang, dan Prospek" (Jakarta: Alvabet), hal. 27, dikutip dalam jurnal Abdul Ghofur Anshori, "Sejarah Perkembangan Hukum Perbankan
}

Zamakhsyari Abdul Majid | Pendekatan Tafsir Dalam Dinamika Perbankan Syariah 
Perbankan syariah sebagai elemen penting dalam hukum perbankan di Indonesia saat ini mengalami perkembangan yang pesat, dimana adanya didukung oleh terbitnya berbagai regulasi secara kelembagaan maupun berkaitan dengan kegiatan usaha. Sistem perbankan konvensional yang telah ada sebelumnya menjadi semakin lengkap dengan diintrodusirnya sistem perbankan syariah sehingga diharapkan dapat memenuhi kebutuhan semua elemen masyarakat akan jasa perbankan tanpa perlu "ragu" lagi mengenai boleh/tidaknya memakai jasa perbankan terutama jika ditinjau dari kaca mata agama. Bahwa yang menjadi kritik sistem perbankan syariah terhadap perbankan konvensional bukan dalam hal fungsinya sebagai lembaga intermediasi keuangan (financial intermediary institution), akan tetapi karena di dalam operasionalnya terdapat unsur-unsur yang dilarang, berupa unsur perjudian (maisyrir), unsur ketidakpastian/keraguan (garar), unsur bunga (interest/riba), dan unsur kebațilan. ${ }^{3}$

Dalam catatan sejarah, gagasan untuk mendirikan bank syariah di Indonesia sebenarnya sudah muncul sejak pertengahan tahun 1970-an. Hal ini dibicarakan pada seminar nasional Hubungan Indonesia-Timur Tengah pada 1974 dan pada tahun 1976 dalam seminar internasional yang diselenggarakan oleh lembaga Studi IImu-IImu Kemasyarakatan (LSIK) dan Yayasan Bhineka Tunggal lka. Namun. ada beberapa alasan yang menghambat terealisasinya idea tau gagasan tersebut. yakni:

1. Operasi bank syariah yang menerapkan prinsip bagi hasil belum diatur, dan Karena itu, tidak sejalan dengan UU Pokok Perbankan yang berlaku, yakni UU No. 14/1967.

2. Konsep bank syariah dari segi politis berakomodasi ideologis, merupakan bagian dari atau berkaitan dengan konsep Negara Islam, dan karena itu tidak dikehendaki pemerintah.

3. Masih dipertanyakan, siapa yang bersedia menaruh modal dalam ventura semacam itu. ${ }^{4}$

Akhirnya gagasan mengenai bank syariah itu muncul lagi sejak tahun 1988, di saat pemerintah mengeluarkan Paket Kebijakan Oktober (Pakto) yang berisi liberalisasi industri perbankan. Para ulama pada waktu itu berusaha untuk mendirikan bank bebas bunga, tapi tidak ada satupun perangkat hukum yang dapat dirujuk, kecuali bahwa perbankan dapat saja menetapkan bunga sebesar $0 \%$. Setelah adanya rekomendasi dari lokakarya ulama tentang bunga bank dan perbankan di Cisarua, Bogor

Syariah di Indonesia dan Implikasinya bagi Praktik Perbankan Nasional”, Jurnal Ekonomi Islam, Vol. II, No. 2, Desember 2008

3 Abdul Ghofur Anshori (2008), "Perkembangan Hukum, Kelembagaan, dan Operasional Perbankan Syariah di Indonesia", Makalah yang disampaikan pada Kuliah Perdana Magister Hukum Bisnis dan Kenegaraan FH UGM, Multimedia Room FH UGM Yogyakarta, tanggal 14 Juni 2008, hal. 1, dikutip dalam jurnal Abdul Ghofur Anshori, "Sejarah Perkembangan Hukum Perbankan Syariah di Indonesia dan Implikasinya bagi Praktik Perbankan Nasional", Jurnal Ekonomi Islam, Vol. II, No. 2, Desember 2008

${ }^{4}$ Muh. Dawam Rahardjo, Islam dan Transformasi Sosial-Ekonomi(Jakarta; Lembaga Studi Agama dan Filsafat, 1999), hlm. 405. Dikutip dalam jurnal Saifullah Bombang,"Prospek Perbankan Syariah Di Indonesia", Jurnal Diskursus Islam, Volume 1 Nomor 2, Tahun 2013

Zamakhsyari Abdul Majid | Pendekatan Tafsir Dalam Dinamika Perbankan Syariah 
tanggal 19-22 Agustus 1990, yang kemudian dibahas lebih mendalam pada Musyawarah Nasional (Munas) IV Majelis Ulama Indonesia menjalankan kegiatan usahanya berdasarkan prinsip syariah Umum Syariah dan Bank Pembiayaan Rakyat Syariah (Pasal 1 angka 7 UU Perbankan Syariah. Karena itu, jika disebut Perbankan Syariah, maka ia merujuk pada Bank Umum Syariah (BUS), Unit Usaha Syari'ah (UUS), dan Bank Pembiayaan Rakyat Syariah (BPRS). Sedangkan jika disebut Bank Syariah, maka hanya merujuk pada BUS dan BPRS. Jika disebut BUS atau UUS, atau BPRS, maka hanya merujuk pada istilah yang disebut tadi.

Berkaitan dengan kelembagaan, UU Perbankan Syariah menentukan bahwa Bank Konvensional yang melaksanakan layanan Syariah, harus terlebih dahulu membuka UUS (Pasal 5 ayat 9 UU Perbankan Syariah). Selanjutnya, UU Perbankan Syariah mendorong agar UUS menjadi BUS. Untuk itu, UU Perbankan Syariah menekan bahwa "dalam hal Bank Umum Konvensional memiliki UUS yang nilai asetnya telah mencapai paling sedikit $50 \%$ (lima puluh perseratus) dari total nilai asset bank induknya atau 15 (lima belas) tahun sejak berlakunya UU ini, maka Bank Umum Konvensional dimaksud melakukan pemisahan UUS tersebut menjadi BUS" (Pasal 68 UU Perbankan Syariah). Disamping itu, UU Perbankan Syariah menetapkan pula bahwa BUS, UUS atau BPRS tidak boleh dialihkan menjadi Bank Umum Konvensional atau BPR (Pasal 5 ayat 7 dan 8 UU Perbankan Syariah). ${ }^{5}$

\section{B. METODOLOGI}

Artikel ini menggunakan studi kualitatif. Di mana penelitian ini merupakan penelitian yang biasanya berkaitan dengan sosial yang lebih membutuhkan deskripsi daripada hanya sekadar angka. Hasil dari penelitian kualitatif adalah deskripsi serta analisis tentang kegiatan, dan juga peristiwa-peristiwa penting. Masukan yang sangat penting untuk menyempurnakan praktik adalah beberapa studi kasus yang dilakukan secara terpisah pada kurun waktu yang berbeda terhadap fokus masalah, kegiatan dan program yang sama.

\section{PEMBAHASAN}

Perbankan syariah merupakan pioner lembaga keuangan Islam di Indonesia. Perkembangan lembaga tersebut mengalami kemajuan yang signifikan baik secara kelembagaan maupun respon masyarakat. Perkembangan perbankan tersebut diikuti lembaga keuangan lain seperti, asuransi, pegadaian dan pasar modal. Berbagai kajian, penelitian dan penyempurnaan terus dilakukan baik oleh kalangan akademisi dan non

5 Saifullah Bombang, "Prospek Perbankan Syariah Di Indonesia”, Jurnal Diskursus Islam, Volume I Nomor 2, Tahun 2013

Zamakhsyari Abdul Majid | Pendekatan Tafsir Dalam Dinamika Perbankan Syariah 
akademisi. ${ }^{6}$ Perbankan syariah sebagai elemen penting dalam hukum perbankan di Indonesia saat ini mengalami perkembangan yang pesat, dimana adanya didukung oleh terbitnya berbagai regulasi secara kelembagaan maupun berkaitan dengan kegiatan usaha. Sistem perbankan konvensional yang telah ada sebelumnya menjadi semakin lengkap dengan diintrodusirnya sistem perbankan syariah sehingga diharapkan dapat memenuhi kebutuhan semua elemen masyarakat akan jasa perbankan tanpa perlu "ragu" lagi mengenai boleh/tidaknya memakai jasa perbankan terutama jika ditinjau dari kaca mata agama. Bahwa yang menjadi kritik sistem perbankan syariah terhadap perbankan konvensional bukan dalam hal fungsinya sebagai lembaga intermediasi keuangan (financial intermediary institution), akan tetapi karena di dalam operasionalnya terdapat unsur-unsur yang dilarang, berupa unsur perjudian (maisyrir), unsur ketidakpastian/keraguan (garar), unsur bunga (interest/riba), dan unsur kebatilian. ${ }^{7}$

Perbankan Islam di Indonesia memiliki sejarah yang panjang dan melalui proses yang rumit. Secara formalnya perkembangan perbankan Islam di Indonesia baru dimulai pada tahun 1992, akan tetapi perkembangan perbankan Islam di Tanah Air sebenarnya sudah dimulai secara formal dan informal jauh sebelum tahun tersebut. Ide awal tentang perlunya satu lembaga keuangan perbankan berbasis Islam di Indonesia muncul dengan adanya pendapat yang disampaikan oleh K.H. Mas Mansur, ketua pengurus besar Muhammadiyah periode 1937-1944 dimana beliau telah menguraikan tetang penggunaan bank konvensional sebagai hal yang terpaksa dilakukan karena umat Islam belum mempunyai bank sendiri yang bebas riba (Dewi, 2004: 60). ${ }^{8}$

Pada masa sebelum tahun 1988 bank Islam belum dapat berdiri karena pada masa tersebut pemerintah masih menetukan tingkat suku bunga yang berlaku dalam perbankan. Kebijakan yang dilakukan oleh pemerintah ini pada akhirnya justru tidak efisien, karena terjadi perbedaan antara tingkat bunga dipasaran dengan tingkat bunga resmi, dimana pemerintah memberikan subsidi terhadap selisih kedua tingkat bunga tersebut (Perwataatmaja, Karnaen dan Hendri Tanjung, 2006).

Dengan adanya kebijakan yang dilakukan oleh pemerintah ini membuat dunia perbankan Indonesia menjadi tidak efisien. Untuk mencegah agar hal tersebut tidak terjadi dan berkepanjangan, maka pemerintah mengeluarkan paket kebijakan ekonomi pada tanggal 1 Juni 1983. Dalam paket tersebut ditegaskan bahwa bank-bank milik pemerintah diberikan kebebasan untuk menentukan tingkat bunganya sendiri. Karnaen Perwataatmaja, salah seorang pelopor pendirian bank Islam melihat peluang untuk mendirikan bank Islam dengan menyatakan bahwa bank

6 Safiq M. Hanafi, "Perkembangan Perbankan Islam di Indonesia antara Teori dan Fakta", Jurnal

Penelitian Agama, Volume XVII Nomor 2 Mei-Agustus 2008

7 Abdul Ghofur Anshori, op.cit

8 Nurul Huda \& Mohamad Heykal, "Lembaga Keuangan Islam: Tinjauan Teoritis dan Praktis", (Jakarta: 2010) Kencana, hlm. 29

Zamakhsyari Abdul Majid | Pendekatan Tafsir Dalam Dinamika Perbankan Syariah 
tersebut adalah bank dengan bunga $0 \%$. Namun dalam kenyataannya hingga Oktober 1988 belum ada satu pun bank Islam yang berdiri dikarenakan pada saat itu izin mendirikan bank baru belum dikeluarkan oleh pemerintah. Barulah setelah pemerintah mengeluarkan paket kebijakan Oktober 1988 mulai dilakukan berbagai upaya intensif pendirian bank Islam di Indonesia.

Paket kebijakan Oktober (Pakto) 1988 sendiri merupakan paket kebijakan yang mengatur deregulasi industri perbankan di Indonesia. Seperti diketahui bahwa para ulama pada saat itu telah berusaha untuk mendirikan bank bebas bunga, tetapi tidak ada satu pun perangkat hukum yang dapat dirujuk kecuali adanya penafsiran dari peraturan perundangundangan yang ada bahwa perbankan dapat saja menetapkan bunga sebesar 0\%. Penafsiran ini disampaikan oleh Karnaen Perwataatmaja. (Arifin, 2002: 7)

Setelah dikeluarkan Pakto 1988 yang berisi tentang liberalisasi perbankan yang memungkingkan pendirian bank-bank baru selain yang telah ada, dimulailah pendirian bank-bank perkreditan rakyat dengan basis sistem Islam dibeberapa daerah di Indonesia. Yang pertama kali mendapat izin usaha adalah Bank Perkreditan Rakyat Syariah (BPRS) Berkah Amal Sejahtera Dana Mardhatillah pada tanggal 19 Agustus 1991, serta BPRS Amana Rabaniah pada tanggal 24 Oktober 1991 yang ketiganya beroperasi di Bandung, dan BPRS Hareukat pada tanggal 10 November 1991 di Aceh. (Dewi, 2004: 61)

Keberadaan BPRS tersebut mendorong untuk didirikannya bank umum yang bebas dari bunga. Hanya kurang dari dua tahun semenjak paket kebijakan Oktober 1988 tersebut dikeluarkan, pada tanggal 19-22 Agustus 1990 diadakan lokakarya Ulama tentang bunga bank dan perbankan di Cisarua, Bogor. Dari hasil lokakarya tersebut kemudian dibahas lebih mendalam pada Musyawarah Nasional IV Majelis Ulama Indonesia (MUI) yang berlangsung di Jakarta, pada tanggal 22-25 Agustus 1990, yang kemudian merekomendasikan untuk dibentunya sebuah lembaga keuangan syariah dengan dibentuknya sebuah kelompok kerja.

Pada akhirnya, permintaan yang ada dari sebagian kalangan masyarakat tersebut dijawab oleh pemerintah dengan sebuah respons positif pada tahun 1991, yaitu dengan didirikannya PT Bank Muamalat Indonesia malalui akta pendirian yang ditanda tangani pada 1 November 1991. Melalui proses pengumpulan modal yang dilakukan oleh Presiden RI saat itu alm. Soeharto pada 3 November 1991 terkumpul komitmen modal disetor untuk PT Bank Muamalat sebesar Rp. 106.126.382.000. dengan rangkaian proses tersebut, maka pada 1 Mei 1992 Bank Muamalat Indonesia mulai beroperasi.

Kemudian pada tahun 1992 perkembangan perbankan islam mendapatkan angin segar seiring dengan dikeluarkannya UU No. 7 tahun 1992 tentang Perbankan yang menandai dimulainya era sistem perrbankan Islam di Indonesia, meskipun pada waktu belum disebutkan secara jelas akan konsep perbankan Islam, hanya disebutkan bank yang beroperasi 
dengan konsep bagi hasil, yaitu pada pasal 13 ayat (c). Sehubungan dengan lahirnya UU tersebut, pada tanggal 30 Oktober 1992 pemerintah mengeluarkan Peraturan Pemerintah (PP) No. 72 Tahun 1992 tentang bank yang beroperasi dengan prinsip bagi hasil dan lalu peraturan tersebut diundangkan pada 30 Oktober 1992.

Meskipun sudah mendapatkan legalitas operasional untuk beroperasi di Indonesia, selama lima tahun setelahnya, lembaga perbankan Islam seperti lembaga yang "jalan di tempat", tidak berkembang pesat, akan tetapi jelas tidak diharapkan kehancurannya oleh banyak kalangan. Bersamaan dengan itu, Indonesia, negara yang sebelumnya dikategorikan sebagai calon negara industri baru, tertimpa krisis moneter yang sangat parah yang berimbas pada krisis ekonomi dan krisis politik yang berkepanjangan. Sebagai akibatnya, perbankan konvensional juga mengalami imbas yang sama parahnya akibat dari krisis tersebut. Pada hari Sabtu, 1 November 1997, kerusakan dunia perbankan di Indonesia mulai terlihat ketika pemerintah memutuskan untuk menutup enam belas bank secara bersamaan karena keenam belas bank tersebut sudak tidak layak untuk beroperasi. Sebagai akibat dari langkah penutupan tersebut, kepercayaan masyarakat terhadap dunia perbankan langsung runtuh seketika. Untuk meredam kepanikan yang ada pada masyarakat, pemerintah menerbitkan Keppres 26 tahun 1998 tentang Penjaminan Dana Pihak Ketiga yang ada di perbankan, serta membetuk Badan Penyehatan Perbankan Nasional (BPPN). Langkah yang diambil oleh pemerintah ini seolah menunjukan bahwa keputusan yang diambil pada 1 November 1997 ini bukan yang terakhir. Dan ternyata tepat, hanya menjelang satu bulan lebih menjelang kejatuhannya, tepatnya pada 4 April 1998, pemerintah Presiden Soeharto alm. kembali menutup keenam belas bank yang bermasalah melalui pengumuman yang diumumkan oleh Menter Keuangan Fuad Bawazier, kepala BPPN Iwan R. Prawiranataserta wakil kepala BPPN Rini MS Soewandi.

Berbagai penutupan yang dilakukan oleh pemerintah tersebut ternyata hanya terjadi pada bank konvensional, karena perbankan konvensional pada saat itu banyak mengalami kerugian akibat negative spread. Perbankan Islam justru tidak mengalami krisis negative spread tersebut, dan hanya berdampak pada kerugian operasional perusahaan. Dalam masa tersebut perbankan Islam menunjukan ketangguhannya pada awal krisis moneter yang menimpa Indonesia pada 1997-1998 yang merupakan masa terberat bagi seluruh sistem perekonomian Indonesia. Pada masa tersebut, ketangguhan perbankan Islam tidak lepas dari tingginya tingkat kepercayaan para nasabah perbankan Islam terhadap bank Islam satu -satunya saat itu, yaitu PT Bank Muamalat Indonesia di Tanah Air.

Sementara itu perbankan konvensional justru dilanda ketidak percayaan yang tinggi dari kalangan masyarakat. Hal itu mengakibatkan banyak bank konvensional yang berusaha untuk menarik dana dari masyarakat dengan imbalan tingkat suku bunga tabungan dan deposito

\section{Zamakhsyari Abdul Majid | Pendekatan Tafsir Dalam Dinamika Perbankan Syariah}


yang tinggi, bahkan ada yang mencapai $73 \%$. Sementara itu, tingkat suku bunga kredit yang ada saat itu dalam perbankan konvensional hanya mencapai batas 35\%. Bahkan dalam kenyataanya tidak ada yang mencapai nilai sebesar itu, karena rata-rata bank konvensional hanya berani memberikan kredit dengan tingkat bunga maksimal 30,74\% (data situs resmi Bank Indonesia). Yang terjadi akibatnya adalah bencana bagi perbankan konvensional karena adanya spekulasi yang tinggi dikalangan masyarakat untuk memercayakan dana mereka dikelola oleh perbankan konvensional dengan harapan akan mendapatkan bunga yang tinggi kepada masyarakat. Hal inilah yang mengakibatkan banyak perbankan konvensional mengalami kesulitan keuangan dan mengakibatkan terjadinya negative spread yang sedemikian besar diperbankan konvensional yang pada akhirnya telah mengakibatkan tingginya biaya modal bagi sektor usaha yang berakibat merosotnya kemampuan usaha sektor produksi. Kualitas aset perbankan turun secara drastis. Sementara disaat itu pula dalam rangka bertahan hidup jajaran perbankan konvensional berusaha untuk terus menarik dana-dana masyarakat dengan memberikan imbalan kepada para deposan mereka sesuai dengan tingkat suku bunga pasar. Akan tetapi, hal ini menimbulkan dampak negative kepada sektor riil dan industri karena perbankan konvensional menghindari untuk memberikan kredit dengan bunga rendah kepada sektor tersebut. Ini mengakibatkan industri dan sektor produksi mengalami penurunan kinerja mereka secara signifikan dan mengakibatkan rendahnya kemampuan daya saing usaha pada sektor produksi. Dalam masa tersebut justru perbankan Islam dapat menunjukan kinerja yang relatif baik dibandingkan dengan lembagaperbankan konvensional. Hal ini dapat dilihat dari relatif lebih rendahnya pembiayaan yang bermasalah (non-peforming financing) pada bank Islam dan tidak terjadinya negatif spread dalam kegiatan operasionalnya. Hal tersebut dapat dipahami mengingat tingkat pengembalian pada bank Islam tidak mengacu pada tingkat suku bunga tabungan dan deposito yang telah ditetapkan oleh Bank Indonesia karena perbankan Islam tidak menganut sistem bunga dan pada akhirnya dapat menyediakan dana investasi dengan "biaya" yang relatif lebih rendah kepada masyarakat.

Apa yang terjadi pada perbankan Islam ini akhirnya dilihat sebagai fakta yang mendasar oleh pemerintah. Pemerintah reformasi pertama pimpinan Presiden BJ. Habibie, yang merupakan salah seorang intelektual muslim Indonesia memberikan kekuatan baru atas dasar legal-formal perbankan Islam di Tanah Air dengan mengeluarkan UU No. 10 tahun 1998 tentang perbankan yang menandai dual banking system di Tanah Air, di mana perbankan Islam di sebutkan secara jelas di situ. Dengan berlakunya UU tersebut, maka Peraturan Pemerintah No. 72 tahun 1992 dicabut dan dinyatakan tidak berlaku lagi. Pencabutannya dituangkan dalam Peraturan Pemerintah No. 30 tahun 1999 tentang Pencabutan Pemerintah No. 70 tahun 1992 tentang Bank Umum sebagaimana telah beberapa kali dirubah, terakhir dengan Peraturan Pemerintah No. 73 tahun 1998, Peratuan 
Pemerintah No. 71 tahun 1992tentang Bank Perkreditan Rakyat dan Peraturan Pemerintah No. 72 tentang Bank berdasarkan Prinsip Bagi Hasil. (Usman, 2002: 47)

Dalam UU tersebut diatur dan diberikan landasan hukum serta berbagai jenis usaha yang dapat di operasikan dan diimplementasikan secara langsung oleh perbankan Islam, termasuk juga petunjuk yang diperlukan bagi bank-bank konvensional untuk membuka unit usaha Islam atau mengonversikan secara total untuk menjadi bank umuum Islam. Langkah ini memberikan peluang bagi dunia perbankan konvensional untuk juga membuka unit usaha Islam ataupun secara total mengonversikan kegiatan usahanya menjadi bank Islam. Peluang ini kemudian di lihat oleh PT Bank Susila Bakti yang dimiliki oleh yayasan Karyawan Bank Dagang Negara untuk keluar dari krisis dengan mengonversi jenis usahanya menjadi bank umum Islam dengan nama PT Bank Islam Mandiri sesudah proses penyehatan bank tersebut dilaksanakan. Dual banking system sendiri sudah dimulai seiring dengan berlakunya UU No. 7 tahun 1992 tentang Perbankan, dimana diakui beroperasinya bank dengan konsep bagi hasil dan tanpa bunga.

Dunia Islam kembali mendapatkan angin segarpada 2008 dengan disahkannya UU tentang Perbankan Islam, yaitu UU No. 21 tahun 2008. Undang-undang dengan 13 bab dan 70 pasal yang disahkan oleh Presiden SBY pada 16 Juli 2008 ini diharapkan dapat mempercepat proses akselerasi perkembangan perbankan Islam, sehingga diharapkan pada 2010 pangsa pasar perbankan Islam telah mencapai 5\% dari pangsa pasar perbankan secara nasional. Hingga saat ini di Indonesia, jumlah perbankan Islam yang telah beroperasi terdiri dari 5 bank umum Islam, 27 unit usaha Islam serta 131 BPRS yang ada di seluruh Indonesia. Selain itu, total aset perbankan Islam adalah $2,05 \%$ dari seluruh pangsa pasar perbankan Islam di Indonesia.

Urutan sejarah dan perkembangan perbankan Islam di Tanah Air dapat dilihat dalam rincian ringkas dibawah ini:

1. 1974: berupa ide dalam seminar nasional hubungan IndonesiaTimur Tengah. Belum terealisasi karena UU yang belum memungkinkan dan adanya hambatan politis.

2. 1988: PAKTO 1988. Kebijakan pemerintah untuk meliberalisasi perbankan Indonesia membuka peluang baru. Belum ada dasar hukum, kecuali adanya klausul dalam PAKTO yang menyebutkan bahwa bank dapat menerapkan bunga sebesar $0 \%$.

3. 1990: lokakarya ulama tentang bunga bank dan perbankan di Cisarua, Bogor. Hasilnya adalah keputusan untuk membentuk kelompok kerja yang akan mendirikan bank Islam di Tanah Air

4. 1991: 1 November, akta pendirian BMl ditandatangani, 3 November presiden Soeharto membantu pengumpulan dana untuk pendidikan BMI di Istana Bogor.

5. 1992: 1 Mei, BMI mulai beroperasi. UU No. 7 Tahun 1992 keluar dan mengakomodasi perbankan dengan konsep bagi hasil. 
Keluar pula PP No. 72 Tahun 1992 tentang Bank Berdasarkan Prinsip Bagi Hasil.

6. 1997-1998: Indonesia dilanda krisis moneter terparah. Banyak bank konvensional tumbang karena CAR negatir dan mengalami kerugian negative spread.

7. 1998: UU No. 10 Tahun 1998 lahir. UU ini memberikan peluang bagi pengembangan perbankan Islam. Dengan begitu dual banking system berlaku tanpa "malu-malu" lagi. Dengan adanya UU tersebut, maka bank konvensional juga boleh membukan Unit Usaha Syariah.

8. 1999: UU No. 23 Tahun 1999 tentang BI. Dalam UU ini disebutkan bahwa $\mathrm{BI}$ bertanggung jawab terhadap pengawasan perbankan termasuk perbankan Islam.

9. 2008: UU No. 21 Tahun 2008 disahkan dalam masa pemerintahan Presiden Susilo Bambang Yudhoyono. ${ }^{9}$

\section{DAMPAK PERBANKAN SYARIAH DI INDONESIA}

Di Indonesia, bank syariah yang pertama kali didirikan pada tahun 1992 adalah Bank Muamalah Indonesia (BMI). Walaupun perkembangannya agak terlambat bila dibandingkan dengan negaranegara Muslim lainnya, perkembangan perbankan syariah di Indonesia akan terus berkembang. Bila pada periode 1992-1998 hanya ada satu unit Bank Syariah, maka pada tahun 2005, jumlah bank syariah di Indonesia telah bertambah menjadi 20 unit, yaitu 3 Bank Umum Syariah (BUS), dan 17 Unit Usaha Syariah (UUS). Sementara itu jumlah Bank Pembiayaan Rakyat Syariah (BPRS) hingga akhir tahun 2004 bertambah menjadi 88 buah.

Berdasarkan data Bank Indonesia, prospek perbankan syariah pada tahun 2005 diperkirakan cukup baik. Industri perbankan syariah diprediksi akan berkembang dengan tingkat pertumbuhan yang cukup tinggi. Jika pada posisi November 2004, volume usaha perbankan syariah telah mencapai 14,0 triliun rupiah, dengan tingkat pertumbuhan yang terjadi pada tahun 2004 sebesar $88,6 \%$, volume usaha perbankan syariah di akhir tahun 2005 diperkirakan akan mencapai 24 triliun rupiah. Dengan volume tersebut, diperkirakan industri perbankan syariah akan mencapai pangsa sebesar 1,8\% dari industri perbankan nasional dibandingkan sebesar 1,1\% pada akhir tahun 2004. Pertumbuhan volume usaha perbankan syariah tersebut ditopang oleh rencana pembukaan unit usaha syariah yang baru dan pembukaan jaringan kantor yang lebih luas. Dana Pihak Ketiga (DPK)

9 Loc.cit.

Zamakhsyari Abdul Majid | Pendekatan Tafsir Dalam Dinamika Perbankan Syariah 
diperkirakan akan mencapai jumlah sekitar 20 triliun rupiah dengan jumlah pembiayaan sekitar 21 triliun rupiah di akhir tahun 2005. ${ }^{10}$

Sementara itu, riset yang dilakukan oleh Karim Bussines Consulting pada tahun 2005 menunjukan bahwa total aset bank syariah di Indonesia diperkirakan akan lebih besar dari pada apa yang diproyeksikan oleh Bank Indonesia. Dengan menggunakan KARIM Growth Model, total aset bank syariah si Indonesia diproyeksikan akan mencapai antara 1,92\% sampai $2,31 \%$ dari industri perbankan nasional. Model ini dikembangkan dengan pendekatan rational expectation atau dengan memanfaatkan all relevant information available dan mensimulisasikan proyeksi pertumbuhan aset masing-masing BUS/UUS (organik) dan proyeksi BUS/UUS (non organik) yang kemudian dilahirkan agresi pertumbuhan. ${ }^{11}$

Perkembangan mutakhir perbankan syariah belakangan ini tidak dapat dielakkan. Periode perkembangasnya sudah memasuki periode pemantapan peran dan eksistensi dalam kancah bisnis perbankan nasional dan global. Di mana perbankan syariah sudah tidak beorientasi teologis semata, akan tetapi murni bisnis yang berlandaskan syariah. Untuk itu produk-produk yang menjadi andalan dari sistem perbankan syariah harus merupakan produk yang visibel dan dapat diterima oleh seluruh lapisan dan golongan dalam masyarakat Indonesia.

Setelah fatwa produk itu memasuki masa implementasi, lembaga keuangan syariah masing-masing melakukan interpretasi dengan pendekatan pada dua metode sebagaimana disebutkan sebelumnya. Pada kondisi ini justru bertolak belakang dengan keadaan pada interpretasi pada tingkat pertama, di mana para pelaku interpretasi dengan wawasan fikih dan pengetahuan umum mengenai produk perbankan konvensional, maka pada tingkat kedua ini justru minim kemampuan pemahaman tentang fikih dan hukum transaksi syariah.

Interpretasi yang dilakukan bengkat dari nilai-nilai dasar transaksi yang terdapat dalam sumber-sumber utama ajaran Islam, yaitu Al-Qur'an dan Hadis. Berangkat dari nilai-nilai dasar yang ada ini, selanjutnya para pakar DSN-MUI dapat mengembangkan produk yang memiliki tingkat kesyariahan yang lebih baik dan tidak kaku karena dapat disesuaikan dengan perkembangan industri keuangan dan kebutuhan transaksi dalam masyarakat.

\section{E. PENUTUP}

Sebagaimana yang telah dipaparkan di muka, penyusun menerangkan berbagai sejarah hukum perbankan Islam yang terjadi di Indonesia. Gagasan untuk mendirikan bank syariah di Indonesia

\footnotetext{
10 Direktorat Perbankan Syariah Bank Indonesia, "Laporan Perkembangan Perbankan Syariah Tahun 2004", (jakarta: 2004), hlm. 65, dikutip dalam buku Adiwarman A. Karim, "Bank Islam: Analisis Fiqh dan Keuangan", (Jakarta: 2011) PT Raja Grafindo Persada, hlm. 25

${ }^{11}$ Adiwarman A. Karim, "Bank Islam: Analisis Fiqh dan Keuangan", (Jakarta: 2011) PT Raja Grafindo Persada, hlm. 25-26
}

Zamakhsyari Abdul Majid | Pendekatan Tafsir Dalam Dinamika Perbankan Syariah 
sebenarnya sudah muncul sejak pertengahan tahun 1970-an. Hal ini dibicarakan pada seminar nasional Hubungan Indonesia-Timur Tengah pada 1974 dan pada tahun 1976 dalam seminar internasional yang diselenggarakan oleh lembaga Studi IImu-IImu Kemasyarakatan (LSIK) dan Yayasan Bhineka Tunggal lka.

Kebutuhan untuk melakukan perubahan sistem keuangan perbankan menjadi penting, mengingat sistem perbankan dalam kehidupan ekonomi modern memegang peranan yang cukup dominan, khususnya bagi negaranegara yang berpenduduk muslim. Perubahan sistem dilakukan dengan konseptualisasi sistem perbankan yang bersumber dari intepretasi terhadap konsep dasar Islam.

Agar produk syariah tidak identik dengan produk-produk perbankan konvensional, maka tafsir yang dilakukan pada tingkat pertama harus merujuk langsung kepada sumber ajaran Islam dan kenyataan perkembangan bisnis keuangan dan perbankan.

\section{DAFTAR PUSTAKA}

Anshori Abdul Ghofur, "Sejarah Perkembangan Hukum Perbankan Syariah di Indonesia dan Implikasinya bagi Praktik Perbankan Nasional", Jurnal Ekonomi Islam, Vol. II, No. 2, Desember 2008

Bombang Saifullah, "Prospek Perbankan Syariah Di Indonesia”, Jurnal Diskursus Islam, Volume I Nomor 2, Tahun 2013

M. Hanafi Safiq, "Perkembangan Perbankan Islam di Indonesia antara Teori dan Fakta", Jurnal Penelitian Agama, Volume XVII Nomor 2 MeiAgustus 2008

Huda Nurul \& Mohamad Heykal, "Lembaga Keuangan Islam: Tinjauan Teoritis dan Praktis”, (Jakarta: 2010) Kencana, hlm. 29

A Karim, Adiwarman, "Bank Islam: Analisis Fiqh dan Keuangan", (Jakarta: 2011) PT Raja Grafindo Persada, hlm. 25-26]

James Dandy, An Approach to Money and Banking, London : Staples Press, 1954.

Karnaen A. Purwataatmadja, "Peluang dan Strategi Operasional BMI dalam M. Rusli Karim (ed), Berbagai aspek Ekonomi Islam, Jogjakarta: Tiara wacana dan UII, 1992.

Keputusan Munas Alim Ulama dan Konfrensi Besar Ulama di Bandar Lampung, Jakarta: PBNU, t.t.

Lewis, Mervyn K.dkk, Perbankan Syariah, edisi Indonesia oleh Burhan Wirasubrata, Jakarta: Serambi, 2003.

Masyhuri, A. Azis, Masalah Keagamaan Hasil Muktamar dan Munas Alim Ulama Nahdlatul Ulama, Surabaya: Dinamika Press, 1997.

Muhammad, (ed) Bank Syariah Analisis Kekuatan, Kelemahan, Peluang dan ancaman, Yogyakarta : Ekonisia, 2004.

Muhammad, Konstruksi Mudharabah dalam Bisnis Syari'ah, Jogjakarta : Pusat Studi Ekonomi Islam STIS, 2003.

Zamakhsyari Abdul Majid | Pendekatan Tafsir Dalam Dinamika Perbankan Syariah 
Muhammad, Manajemen Bank Syariah, Yogyakarta; UPP AMP YKPN, 2002. Al-Omar, Fuad (dkk), Islamic Banking Theory, Practice and Challenges, Karachi : Oxford University Press, 1996.

Hasan, PA. Rifai, "Ekonomi Islam: Gagasan, kritik dan harapan", dalam jurnal Ulumul Qur'an, Vol II, No. 91991.

Muslimin. Kebijakan Perbankan Syariah Di Indonesia. Cet 1 ; Makassar : Alauddin Pers, 2011.

al-Mishri, Muhammad bin Mukarra>m ibn Mazhur al-Ifriqi, Lisa>n Al-Arab, Juz 1; Beirut: Darul Lisan al-Arab, \{tt al-Mizzi, Abu al-Hajjaj Yusuf ibn alZaki, Tahzib al-Kamal, Juz. 3. Cet. I; Beirut: Muassasah al-Risalah, 1400 H./1980 M.

Nashiruddin Al-Bani, Muhammad, Irwa' Al Gholil Fi Takhrij Ahadits Manar Al Sabil. Cet : 2 Baerut : Al-Maktab Islami, $1405 \mathrm{H}$

Nasution, Harun. Ensiklopedi Islam Indonesia, Jakarta : Jambatan, 1992.

Poerwadarmita, Kamus Umum Bahasa Indonesia, Jakarta : Balai Pustaka, 1996

Qudamah, Ibnu. Al-Mughni di tahqiq Abdullah bin Abdulmuhsin Al-Turki. Cet : 2 ; t.t. :Hajr $1412 \mathrm{H}$ 